T cells formed stable contacts with DCs that lasted for more than an hour. The T cells expressed activation markers and secreted interleukin-2 and interferon- $\gamma$. In phase three, which started after 24 hours, the T cells dissociated from DCs, and underwent rapid migration and proliferation. When transgenic $\mathrm{CD} 4^{+}$ $\mathrm{T}$ cells were used, a similar threephase pattern of interactions was observed.

It remains to be determined what mechanisms control the phase-tophase transition and how the length of the interactions is controlled.

Elaine Bell

(2) References and links ORIGINAL RESEARCH PAPER Mempel, T. R, Henrickson, S. E. \& von Andrian, U. H. T-cell priming by dendritic cells in lymph nodes occurs in three distinct phases. Nature 427, 154-159 (2004) FURTHER READING von Andrian, U. H. \& Mempel, T. R. Homing and cellular traffic in lymph nodes. Nature Rev. Immunol. 3, 867-878 (2003) WEB SITE

Ulrich von Andrian's lab:

http://cbr.med.harvard.edu/investigators/vonandri an/lab/index.html

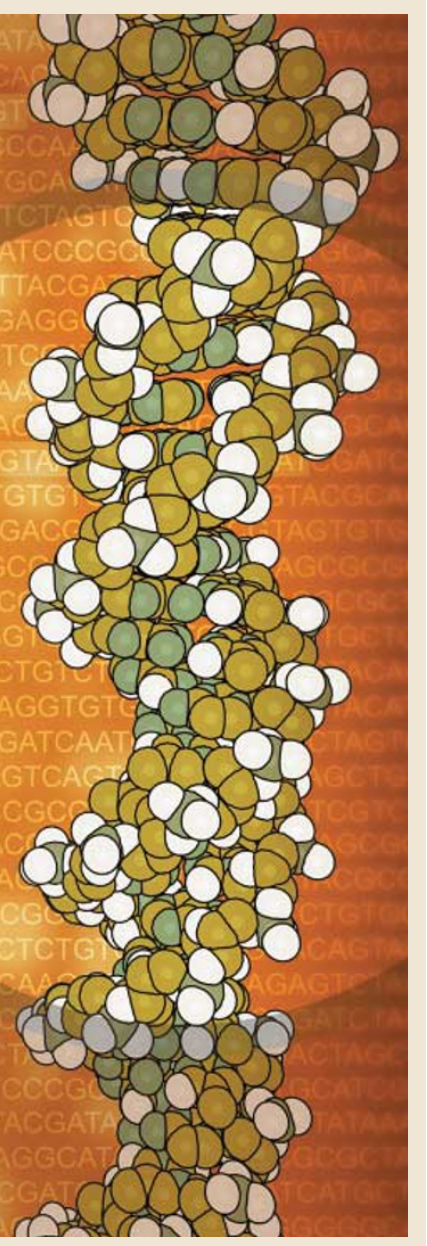

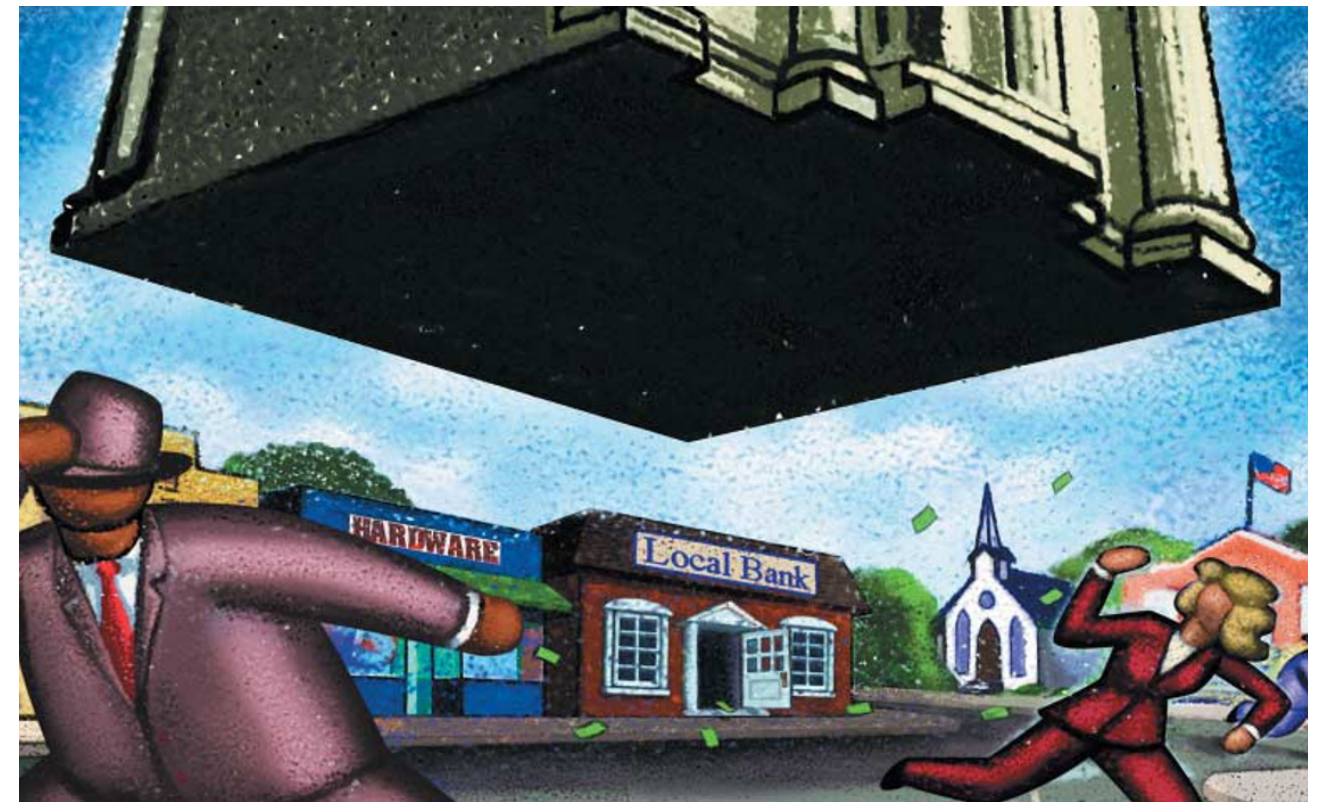

INNATE IMMUNITY

\title{
Microbes mind out!
}

To establish infection, microbial pathogens bind to components of the host extracellular matrix (ECM) and colonize the host. However, according to a recent paper in Nature

Immunology, the secreted ECM protein mindin can also act as a pattern-recognition molecule and is crucial for the initiation of innate immune responses against invaders.

Although previous work has implied that ECM macromolecules might be actively involved in immune defence against microorganisms, this is the first time the role of individual components has been explored. He et al. first cloned mouse Spon2, which encodes mindin, by differential gene expression, and, having established that this gene is highly expressed in lymphoid tissues, generated mindin-deficient mice to investigate the role of this protein in immunity.

The immune system of mindin-deficient mice developed normally, but when the authors tested the response of mindin-deficient mice to lipopolysaccharide (LPS) - a pathogenassociated molecular pattern that is a component of the cell walls of Gram-negative bacteria they found that these mice were resistant to LPS, unlike wild-type mice that all died from LPS-induced septic shock. In wild-type mice, macrophages rapidly produce inflammatory cytokines after exposure to LPS. However, this did not occur in the knockout mice, indicating that mindin is essential for this response. In addition, mindin-deficient macrophages failed to respond to a range of stimuli from Grampositive and Gram-negative bacteria.

What effect does lack of mindin have on immune responses to bacteria? Mindin-deficient mice failed to clear Haemophilus influenzae but not Pseudomonas aeruginosa from the lungs, highlighting a role for mindin in the pulmonary clearance of some, but not all, bacterial pathogens. Mindin-deficient mice were also shown to be more sensitive to systemic infection with Streptococcus pneumoniae, but less sensitive to Salmonella typhimurium than wild-type mice.

These results indicate that mindin interacts with microbial pathogens and acts as a patternrecognition molecule for immune cells. Finally, the authors confirmed this by showing that mindin can bind directly to both Gram-negative and Gram-positive bacteria, and can also act as an opsonin for macrophage phagocytosis of some pathogens.

So, mindin is essential for the initiation of innate immune responses to bacterial pathogens, and functions as a pattern-recognition molecule resident in the ECM, ready and waiting for bacterial invasion.

Jenny Buckland

(9) References and links

ORIGINAL RESEARCH PAPER He, Y.-W. et al. The extracellular matrix protein mindin is a pattern-recognition molecule for microbial pathogens. Nature Immunol. 5, 88-97 (2004)

WEB SITES

You-Wen He's lab:

https://faculty.duke.edu/faculty/info?pid=5573

Michael Bevan's lab:

http://depts.washington.edu/immunweb/faculty/profiles/bevan.html 